\title{
Influence of Cyclic Degradation in Saline Solution on Mechanical Properties of Adhesive Bonds
}

\author{
Miroslav Müller \\ Faculty of Engineering, Czech University of Life Sciences Prague. Czech Republic. E-mail: muller@tf.czu.cz
}

The adhesive bond is the complex of three layers - adhesive bonded material (called adherent), adhesive layer and cohesive layer. Degradation aspects act all parts of the adhesive bond. The aim of this research was the evaluation of influence of degradation environment on the strength of structural two-component epoxy adhesives. Adhesive bonds and process of testing the adhesive bonds were in accordance with standard ČSN EN 1465. The degradation environment in form of $5 \%$ saline solution was used within this experiment. Adhesive bonded testing samples were subjected to cyclic loading of saline solution. On the basis of evaluation of performed experiments it is possible to say, that resulting strength of adhesive bonds decreases at simultaneous acting of environment. The strength of adhesive bond after $8^{\text {th }}$ cycle, i.e. after 56 days, significantly decreased from 67 to $78 \%$. Using the electron microscopy within the experimental research it was proved that the spontaneous failure of the adhesive layer occurred at $8^{\text {th }}$ cycle.

Keywords: adhesive bond strength, corrosive, scanning electron microscopy (SEM), structural two-component epoxy

\section{Acknowledgement}

This paper has been done when solving the grant IGA TF (2015:31140/1312/3106).

\section{References}

[1] MÜLLER, M., VALÁŠEK, P. (2012). Degradation medium of agrokomplex - adhesive bonded joints interaction. In: Research in Agricultural Engineering, Vol. 58, pp. 83-91.

[2] RUDAWSKA, A. (2014). Selected aspects of the effect of mechanical treatment on surface roughness and adhesive joint strength of steel sheets. In: International Journal of Adhesion and Adhesives, Vol. 50, pp. 235-243.

[3] MESSLER, R., W. (2004). Joining of materials and structures from pragmatic process to enabling technology. Burlington: Elsevier, 816 pp.

[4] MÜLLER, M. (2013). Research of Liquid Contaminants Influence on Adhesive Bond Strength Applied in Agricultural Machine Construction. In: Agronomy Research, Vol.11, pp. 147-154.

[5] CIDLINA, J., MÜLlER, M., VALÁŠEK, P. (2014). Evaluation of Adhesive Bond Strength Depending on Degradation Type and Time. In: Manufacturing Technology, Vol. 14, No. 1, pp. 8-12.

[6] MÜLLER, M., HERÁK, D. (2013). Application possibilities of adhesive bonds - Europe, Indonesia. In: Scientia Agriculturae Bohemica, Vol. 44, pp. 167-171.

[7] CROCOMBE, A. D. (1997). Durability modelling concepts and tools for the cohesive environmental degradation of bonded structures. In: International Journal of Adhesion \& Adhesives, Vol. 17, No. 3, p. 229-238.

[8] DOYLE, G., PETHRICK, R. A. (2009). Environmental effects on the ageing of epoxy adhesive joinst. In: International Journal of Adhesion \& Adhesives, Vol. 29, p. 77-90.

[9] SARGENT, J. P., (2005). Durability studies for aerospace applications using peel and wedge tests. In: International Journal of Adhesion \& Adhesives, Vol. 25, p. 247-256.

[10]COMYN, J. (1983). Kinetics and Mechanism of Environmental Attack. Durability of structural adhesives. Reprinted. Ed. Kinloch A. J. London: Applied Science, p. 85-131.

[11]MÜLLER, M., RUŽBARSKÝ, J., VALÁŠEK, P. (2014). Degradation process in area of connecting metal sheets by adhesive bonding technology in agrocomplex. In: Applied Mechanics and Materials, Vol. 616, pp. 52-60.

[12]PERAIRA, A. M., REIS, P.N.B., FERREIRA, J.A.M., ANTUNES, F.V. (2013). Effect of saline environment on mechanical properties of adhesive joints. In: International Journalof Adhesion and Adhesives, Vol. 65, No. 47, p. 99-104.

[13]VALÁŠEK, P. (2014). Long-term degradation of composites exposed to liquid environments in agriculture. In: Scientia Agriculturae Bohemica, Vol. 3, No. 1, pp 187-192. 
[14]MÜLLER, M., HERÁK, D., VALÁŠEK, P. (2013). Degradation limits of bonding technology depending on destinations Europe, Indonesia. In: Tehnicki Vjesnik- Technical Gazette, Vol. 20, pp. 571-575.

[15]KINLOCH, A. J., OSIYEMI, S. O. (1993). Predicting the fatigue life of adhesively-bonded joints. In: Journal of adhesion, Vol. 43, No. 12, p. 79-90.

[16]CROCOMBE, A. D. (1997). Durability modelling concepts and tools for the cohesive environmental degradation of bonded structures. In: International Journal of Adhesion \& Adhesives, Vol. 17, No. 3, p. 229-238.

[17]COURT, R. S., SUTCLIFFE, M.P.F., TAVAKOLI, S.M. (2001). Ageing of adhesively bonded joints - fracture and failure analysis using video imaging techniques. In: International Journal of Adhesion \& Adhesives, vol 21, p. $455-463$.

[18]LOH, W.K, CROCOMBE, A.D, ABDEL WAHAB, M.M., ASHCROFT, I.A. (2002). Environmental degradation of the interfacial fracture energy in anadhesively bonded joint. In: Engineering Fracture Mechanics, Vol. 69, No. 18 , p. 2113-2128.

[19]RUGGIERO, A., VALÁŠEK, P., MEROLA, M. (2015). Friction and wear behaviors of Al/Epoxy Composites during Reciprocating Sliding tests. In: Manufacturing technology, Vol. 15, No. 4, p. 684-689.

[20]DAVIS, M., BOND, D. (1999). Principles and practices of adhesive bonded structural joints and repairs. In: International Journal of Adhesion \& Adhesives, Vol. 19. p. 91-105. 